\title{
CLINICAL PROFILE OF HEPATITIS B VIRUS INFECTION IN PATIENTS ATTENDING TERTIARY CARE CENTRE IN EASTERN INDIA
}

\author{
Champa Chakraverty1, Sekhar Chakraborty2, Kingshuk Bhattacharjee 3 \\ 1 Post Graduate Trainee, Department of Microbiology, MGM Medical College \& Lion's Seva Kendra Hospital. \\ 2RMO-Cum Clinical Tutor, Department of Nephrology, North Bengal Medical College and Hospital. \\ ${ }^{3}$ Assistant Manager, Medical Services, Biocon Limited.
}

\section{ABSTRACT}

\section{AIMS}

A cross-sectional Study, performed in two tertiary care referral clinics to determine the clinical profile of Hepatitis B patients attending tertiary care centres in Eastern India. Patients were segregated as symptomatic and asymptomatic.

\section{RESULTS}

The age of the patients varied from 16-76 years. The mean age of the patients was found to be 34.54 years with a standard deviation of 13.53 years. Only $16 \%$ of the patients were symptomatic on presentation. Common clinical features were nausea (22\%), splenomegaly (22\%), jaundice (13\%), abdominal pain (19\%) and hepatomegaly (10\%). Bilirubin and alanine transaminase (ALT) levels were significantly higher in symptomatic patients. Strong significant positive correlation found between AST and Bilir ubin $(\mathrm{r}=0.346), \mathrm{p}$ value $=0.0004$; ALT and Bilirubin are positively correlated $(\mathrm{r}=0.298), \mathrm{p}$ value $=0.003$; ALT and AST are positively correlated( $r=0.710)$, $p$ value $=<0.0001$; ALT and Albumin are positively correlated( $r=0.216)$, $p$ value $=0.031$ (Moderate significant correlation) in the entire study population.

\section{CONCLUSION}

The current study demonstrates the clinical and biochemical features that a hepatitis B infected patient may present with. Most of the patients with hepatitis B are asymptomatic (84\%) on presentation. To our knowledge, this is the first paper reported from Eastern India in recent times which has shed a light on the differences in the pattern of the biochemical parameters among the symptomatic and asymptomatic hepatitis B infected patients.

\section{KEYWORDS}

Hepatitis B, Clinical Profile, Asymptomatic, Symptomatic, Eastern India.

HOW TO CITE THIS ARTICLE: Chakraverty C, Chakraborty S, Bhattacharjee K. Clinical profile of hepatitis B virus infection in patients attending tertiary care centre in eastern India. J. Evolution Med. Dent. Sci. 2016;5(37):2229-2233, DOI: 10.14260/jemds/2016/518

\section{INTRODUCTION}

Hepatitis B virus (HBV) is one of the commonest and leading causes for hepatobiliary disorders, end-stage liver diseases. ${ }^{1}$ The virus associated diseases are reported all across the globe but its prevalence seems to be on the higher side particularly in the Southeast Asia, sub-Saharan Africa, and the Amazon Basin. ${ }^{2}$ A national symposium on hepatitis B infection in India reported a carrier rate of $4.7 \%$ across India. ${ }^{3}$ Notwithstanding many studies are available on the prevalence of hepatitis $B$ infections both in adult and paediatric population. ${ }^{4}$, it has been observed that there is paucity of data on the clinical and demographic profile of these patients particularly in patients from Bihar and adjoining part of West Bengal (Eastern India ). Furthermore, very few studies have tried to segregate the patients based on their symptoms and tried to evaluate their biochemical profile accordingly. This study is conceived to demonstrate the clinical and demographic profile of hepatitis $B$ in the adult population referred to our tertiary care centre in Eastern India. We further subdivided the patients into two cohorts namely C1 (Symptomatic) and C2 (Asymptomatic).

Financial or Other, Competing Interest: None.

Submission 22-03-2016, Peer Review 18-04-2016,

Acceptance 23-04-2016, Published 09-05-2016.

Corresponding Author:

Champa Chakraverty,

547, Dumdum Park,

Kolkata-700055,

Dist. North 24 Paraganas,

West Bengal.

E-mail: dr.cchakra@gmail.com

DOI: $10.14260 /$ jemds $/ 2016 / 518$
Patients were grouped in C1 cohort on presentation as, being symptomatic if they had jaundice or abdominal pain on history or C2 (Asymptomatic) if they were found to be HBsAg positive on screening and had no symptoms. We compared the biochemical profile among the two cohorts to detect statistically significant difference, if any.

\section{MATERIALS AND METHODS}

The investigation was conducted among HBsAg seropositive patients attending for treatment in tertiary care hospital, MGM Medical College, Kishanganj, Bihar and The North Bengal Medical College, Susrut Nagar, Darjeeling, West Bengal. The study period was from November 2012 to November 2013. The study was done after proper ethical clearance from the Institutional Ethics Committee. A written informed consent was taken from the patients.

\section{Study Design}

Cross-sectional Study, performed in two tertiary care referral clinics.

All patients with positive HBsAg (Newly diagnose) with or without high serum bilirubin irrespective of their age, were screened. Mostly patient presented with insidious onset of jaundice with high ALT levels were screened for HBsAg test showing positivity. Blood samples were collected from the common collection room (For Biochemistry, Pathology and Microbiology department) by our phlebotomists in the morning hours. Our hospital mainly caters a huge area of Eastern Bihar, neighbouring West Bengal mostly Paschim 
Dinajpur and adjoining area around North Bengal Medical College.

History taking of patients for all the HBsAg positive cases included a thorough and careful history taking was considered in the following points.

1. The history of nausea, vomiting, anorexia and mild fever are noted in the cases of jaundice

2. Never was history of fever, skin rash, polyarthritis, glomerulonephritis searched for.

3. Every two weeks follow up and the biochemical records of liver enzymes tests with special attention to serum bilirubin, ALT/ALK. Phosphatase, serum albumin were searched and a comparative data were monitored for any sudden rise of ALT or any other markers except serum proteins.

4. Patient with history of I.V. drug abuser was also noted.

5. History of sexual exposure were also taken.

6. Any patient admitted in our medicine indoor with earlier history of HBsAg positive record and suffering from fulminant hepatitis were noted and their blood samples were collected for study.

The exclusion criteria of the study were the subjects having age below 10 years and above 76 years and acute fulminant Hepatitis.

\section{Specimen Collection}

All hospital service providers especially paramedical and phlebotomists were accordingly guided regarding this study. The proper collection of specimens with universal precautions were taken. Proper identification code and numbering with name of each and every patient's samples was repeatedly emphasized. Haemolysed blood samples was not accepted in this study.

\section{Blood Volume}

$5 \mathrm{ml}$ blood sample was taken in a vacutainer without any anticoagulant. The container was kept in slanting positions (For at least one hour at room temperature) to obtain a clear, unhaemolysed serum.

\section{Transportation}

Just after clot formation (Within an hour) the sample was transported with proper history sheet and requisitions slip having its own identification (Registration) number and laboratory code number, name, date to the microbiology laboratory.

\section{Serum Separation}

Immediately the serum was collected in a separate vial maintaining adequate precaution to avoid contamination and kept in at $2^{\circ} \mathrm{C}-8^{\circ} \mathrm{C}$ in a freezer.

\section{Specimen Processing}

All the frozen samples were allowed to thaw in a vertical position in the rack without shaking. Once again samples were centrifuged ( $1000 \mathrm{rpm}$ for $15 \mathrm{~min}$ ). It was kept for half an hour at room temp.

\section{Test Done for HBsAg}

Immunochromatographic test was used as primary screening test for HbsAg. A confirmatory ELISA TEST was performed with HEPALISA (J Mitra and Co. pvt.ltd.) The HEPALISA has a sensitivity of $0.1 \mathrm{ng} / \mathrm{ml}$ which is more sensitive to immunochromatographic test. The HEPALISA is approved by WHO for the specificity to identify all the subtypes of $\mathrm{HbsAg}$, i.e dw, adr, ayr and ayw.

\section{Procedure of HBsAg by ELISA \\ Preparation of Reagents}

The incubator was pre warmed to $37^{\circ} \mathrm{C}$. The foil pack was brought to room temperature $\left(20^{\circ} \mathrm{C}-25^{\circ} \mathrm{C}\right)$ before opening, to prevent condensation on the micro well strips. The required number of wells needed for the assay were broken off and placed in the strip holder. The strip holder with the required number of strips were taken into account so that two negative and two positive control should be included in the run while opening the fresh kit. Unused wells were stored at $2^{\circ} \mathrm{C}-8^{\circ} \mathrm{C}$ with desiccant in an aluminium pouch with clamp and rod.

\section{Preparation of Working Wash Buffer}

The buffer concentrate was checked for the presence of salt crystals. If crystals are present in the solution, resolubilisation was done by warming at $37^{\circ} \mathrm{C}$ until all the crystal were dissolved. $25 \mathrm{ml}$ of buffer for each strip were prepared before use. It was mixed well before use. $20 \mathrm{ml}$ of $25 \mathrm{x}$ wash buffer concentrate was mixed with $480 \mathrm{ml}$ of distilled or deionized water. The wash buffer remained stable for two months when stored at $2^{\circ} \mathrm{C}-8^{\circ} \mathrm{C}$.

\section{Preparation of Working Conjugate}

The conjugate concentrate was diluted 1:50 in conjugate diluents. Working conjugate was not stored. A fresh dilution for each assay was prepared in a clean vessel. The quantity of working conjugate solution to be prepared was determined. Before use the solution was mixed thoroughly.

\section{Preparation of Working Substrate Solution}

TMB substrate and TMB Diluent were mixed in 1:1 ratio to prepare the working substrate fresh.

\section{Calculation of Result}

Computation of results were done in absorbance mode with cut-off control against negative control and blank.

\section{Cut -Off Value}

Calculation of Cut - Off control $=$ Half of (Mean Negative Control $(\mathrm{B} 1+\mathrm{C} 1)+0.1)$. Our Cut-off $=0.120$. All the value above 0.120 were taken as positive value. All the value below 0.120 were taken as negative value. (Vide literature- J. Mitra and Co.pvt.ltd.). Batch No- TBMB1209.

\section{Interpretation of Results}

All the immunochromatographic positive results were cross checked with HEPALISA TEST reading. It showed value above the cut off control and so were confirmed to be positive.

\section{Statistical Methods}

Descriptive statistical analysis has been carried out in the present study. Results on continuous measurements are presented on Mean \pm SD (Min-Max) and results on categorical measurements are presented in Number (\%). Significance is assessed at $5 \%$ level of significance. Student $t$ test has been used to find the significance of study parameters between two groups of patients. Chi-square/ Fisher Exact test has been used 
to find the significance of study parameters on categorical scale between two or more groups. Pearson method used to determine correlation among numerical variables. The Statistical software namely SAS 9.2, SPSS 21.0 were used for the analysis of the data.

\section{RESULTS}

\section{Demographic Characteristics}

The age of the patients varied from 16-76 years. The mean age of the patients was found to be 34.54 years with a standard deviation of 13.53 years. The maximum no. of patients (39\%) was in the age group 21-30 years followed by $27 \%$ in $31-40$ years' age group. In the present study, females were predominant and the ratio of female and male i.e. female: male was 1.17:1.00. (Table $1 \& 2$ )

\section{Clinical Features}

Nausea was present in $22 \%$ of study subjects. No significant association found between prevalence of nausea $(p=0.4264$, by pooled chi square method) and age group or gender ( $p=0.5874$, chi square method). (Table $1 \& 2$ )

Abdominal pain was present in $19 \%$ of study subjects. No Gender specific significant association was found between the prevalence of abdominal pain ( $\mathrm{p}$ value-0.8001, Fischer's Exact Test). No significant association was found between the prevalence of abdominal pain \& age group. (Table $1 \& 2$ )

Jaundice was present in $13 \%$ of study subjects. No gender specific significant association was found between the prevalence of jaundice ( $\mathrm{p}$ value-0.1334, Fischer's Exact Test). No significant association was found between the prevalence of jaundice \& age group. (Table $1 \& 2$ )

Enlarged liver was present in $10 \%$ of study subjects. No gender specific significant association was found between the prevalence of jaundice ( $\mathrm{p}$ value-0.7891, chi square test). No significant association was found between the prevalence of enlarged liver $\&$ age group. ( $p$ value- 0.8495 , pooled chi square test). (Table $1 \& 2$ )

Enlarged spleen was present in $22 \%$ of study subjects. No gender specific significant association was found between the prevalence of jaundice ( $p$ value- 0.6351 , chi square test). No significant association was found between the prevalence of enlarged spleen \& age group. (Table $1 \& 2$ )

\section{Biochemical Laboratory Profile}

Among the liver function tests, Serum bilirubin in study subjects ranged from $0.55-2.53 \mathrm{mg} / \mathrm{dl}$. $81 \%$ of study subjects had serum bilirubin less than $1 \mathrm{mg} / \mathrm{dl}$ with a mean of $0.82 \pm 0.11 \mathrm{mg} / \mathrm{dl}, 16 \%$ between $1-2 \mathrm{mg} / \mathrm{dl}$ with a mean of $1.24 \pm 0.29 \mathrm{mg} / \mathrm{dl}$ and only 3 patients had serum bilirubin greater than $2 \mathrm{mg} / \mathrm{dl}$ with a mean of $2.34 \pm 0.17 \mathrm{mg} / \mathrm{dl}$. Serum bilirubin values were moderately significantly higher in females $(1.02 \pm 0.37 \mathrm{mg} / \mathrm{dl})$ than in males $(0.88 \pm 0.30 \mathrm{mg} / \mathrm{dl})(\mathrm{p}$ value- 0.061 ) as determined by student t-test method. (Table $1 \& 2$ )

Serum ALT (Alanine transaminase) in study subjects varied from 16-88 IU/L. 71\% of study subjects had serum ALT less than/equal to $40 \mathrm{IU} / \mathrm{L}$ (within normal range) with a mean of $27.25 \pm 6.76 \mathrm{IU} / \mathrm{L}$ and $29 \%$ had serum ALT greater than 40 IU/L (raised level) with a mean of $52.37 \pm 13.00 \mathrm{IU} / \mathrm{L}$. No significant difference was found between the serum ALT activity of the male subjects $(36.21 \pm 10.51)$ and female subjects $(40.78 \pm 18.52)$ as determined by HEPLISA method. (Table $1 \& 2$ )
Serum AST (Aspartate transaminase) in study subjects ranged from $18-95 \mathrm{IU} / \mathrm{L}$. $63 \%$ of study subjects had serum ALT less than/equal to $40 \mathrm{IU} / \mathrm{L}$ (Within normal range) with a mean of $29.51 \pm 6.57 \mathrm{IU} / \mathrm{L}$ and $37 \%$ had serum ALT greater than 40 IU/L (raised level) with a mean of $54.30 \pm 13.68 \mathrm{IU} / \mathrm{L}$. No significant difference was found between the serum ALT activity of the males $(36.21 \pm 10.51)$ and females (40.78 \pm 18.52$)$. ( $p$ value- 0.128 ) as determined by student $t$ test method. (Table $1 \& 2$ )

Serum albumin in study subjects ranged from 2.20-4.40 gm/dL. $25 \%$ of study subjects had serum albumin in the hypoalbuminaemia range with a mean of $2.74 \pm 0.18 \mathrm{gm} / \mathrm{dL}$ and $47 \%$ above $3.5 \mathrm{gm} / \mathrm{dL}$. No significant difference was found between the serum ALT activity of the males (3.38 \pm 0.51$)$ and females (3.42 \pm 0.49$)$. ( $p$ value- 0.701 ) as determined by student t-test method. (Table $1 \& 2$ )

\section{Correlation among Liver Function Activity Parameters} Strong significant correlation found between AST and Bilirubin are positively correlated $(r=0.346)$, $p$ value $=0.0004$; ALT and Bilirubin are positively correlated( $r=0.298), p$ value $=0.003$; ALT and AST are positively correlated( $r=0.710)$, $\mathrm{p}$ value $=<0.0001 ;$ ALT and Albumin are positively correlated $(r=0.216), \quad p$ value $=0.031$ (moderate significant correlation) in all of the patients. However, no significant correlation found between age and any of the parameters. (Table 3)

\begin{tabular}{|c|c|c|c|c|c|}
\hline Label & N & Mean & Std. Dev. & Min & Max \\
\hline Age & 100 & 34.54 & 13.52 & 16 & 76 \\
\hline Bilirubin & 100 & 0.9577 & 0.34 & 0.55 & 2.53 \\
\hline ALT & 100 & 34.54 & 14.53 & 16 & 88 \\
\hline AST & 100 & 38.68 & 15.48 & 18 & 95 \\
\hline Albumin & 100 & 3.4068 & 0.51 & 2.2 & 4.4 \\
\hline \multicolumn{6}{|c|}{ Table 1: Descriptive Statistics of the Study } \\
Parameters (On Continuous Scale) \\
\hline
\end{tabular}

$\mathrm{N}$-Number of Patients

\begin{tabular}{|c|c|c|}
\hline & \% Present & P value \\
\hline Fever & 5 & \\
\hline Males & 7.41 & \multirow[b]{2}{*}{0.37} \\
\hline Females & 2.17 & \\
\hline \multicolumn{3}{|l|}{ Gender } \\
\hline Male & 54 & \multirow{3}{*}{0.42} \\
\hline Female & 46 & \\
\hline Nausea & 22 & \\
\hline Males & 19.57 & \multirow[b]{2}{*}{0.64} \\
\hline Females & 24.07 & \\
\hline Abdominal Pain & 19 & \\
\hline Males & 17.39 & \multirow[b]{2}{*}{0.801} \\
\hline Females & 20.37 & \\
\hline Jaundice & 13 & \multirow[b]{3}{*}{0.133} \\
\hline Males & 6.52 & \\
\hline Females & 18.52 & \\
\hline Enlarged Liver & 10 & \multirow{3}{*}{1.00} \\
\hline Males & 10.87 & \\
\hline Females & 9.26 & \\
\hline Enlarged Spleen & 22 & \\
\hline Males & 19.57 & \multirow[b]{2}{*}{0.64} \\
\hline Females & 24.07 & \\
\hline $\begin{array}{r}\text { Table } \\
\text { of }\end{array}$ & $\begin{array}{l}\text { Charact } \\
\text { Populati }\end{array}$ & \\
\hline
\end{tabular}




\begin{tabular}{|c|c|c|c|c|c|}
\hline & \multicolumn{2}{|c|}{ Asymptomatic, $\mathbf{n = 8 4}$} & \multicolumn{2}{c|}{ Symptomatic, n=16 } & \multirow{2}{*}{ P } \\
\hline & Mean & Std. Dev. & Mean & Std. Dev. & P. \\
\cline { 1 - 5 } Age & 34.82 & 13.80 & 30.86 & 9.14 & 0.45 \\
\hline Bilirubin & 0.93 & 0.31 & 1.39 & 0.54 & 0.001 \\
\hline ALT & 34.20 & 14.39 & 39.00 & 16.95 & 0.049 \\
\hline AST & 38.60 & 14.87 & 39.71 & 23.76 & 0.64 \\
\hline Albumin & 3.40 & 0.51 & 3.44 & 0.44 & 0.82 \\
\cline { 1 - 4 }
\end{tabular}

Table 3: Comparative Study of the

Asymptomatic and Symptomatic Patients

p $<0.05$ Considered as Statistically Significant.

\begin{tabular}{|c|c|c|c|c|c|}
\hline \multicolumn{6}{|c|}{$\begin{array}{c}\text { Correlation of Biochemical Parameters among Symptomatic } \\
\text { Patients }\end{array}$} \\
\hline \multicolumn{6}{|c|}{ Symptomatic Cohort, $\mathrm{n}=16$} \\
\hline & & Bilirubin & AST & ALT & Albumin \\
\hline \multirow{2}{*}{ Bilirubin } & $\mathrm{r}$ & \multirow{2}{*}{1} & -0.11 & -0.05 & -0.75 \\
\hline & $\mathrm{p}$ & & 0.81 & 0.92 & 0.042 \\
\hline \multirow{2}{*}{ AST } & $\mathrm{r}$ & -0.11 & \multirow{2}{*}{1} & 0.94 & -0.43 \\
\hline & $\mathrm{p}$ & 0.80 & & 0.001 & 0.33 \\
\hline \multirow{2}{*}{ ALT } & $\mathrm{r}$ & -0.045 & 0.94 & \multirow{2}{*}{1} & -0.43 \\
\hline & $\mathrm{p}$ & 0.92 & 0.001 & & 0.33 \\
\hline \multirow{2}{*}{ Albumin } & $\mathrm{r}$ & -0.76 & -0.43 & -0.43 & \multirow[b]{2}{*}{1} \\
\hline & $\mathrm{p}$ & 0.041 & 0.33 & 0.32 & \\
\hline & & elatio & che & Par & \\
\hline
\end{tabular}

$\mathrm{p}<0.05$ Considered as Statistically Significant; $\mathrm{r}-$ Pearson's Correlation Coefficient.

\begin{tabular}{|c|c|c|c|c|c|}
\hline \multicolumn{6}{|c|}{$\begin{array}{l}\text { Correlation of Biochemical Parameters among Asymptomatic } \\
\text { Patients }\end{array}$} \\
\hline \multicolumn{6}{|c|}{ Asymptomatic Cohort, $\mathrm{n}=84$} \\
\hline & & Bilirubin & AST & ALT & Albumin \\
\hline \multirow{2}{*}{ Bilirubin } & $\mathrm{r}$ & \multirow{2}{*}{1.00} & 0.45 & 0.34 & -0.06 \\
\hline & $\mathrm{p}$ & & $<.0001$ & 0.001 & 0.60 \\
\hline \multirow{2}{*}{ AST } & $\mathrm{r}$ & 0.45 & \multirow{2}{*}{1.00} & 0.69 & -0.04 \\
\hline & $\mathrm{p}$ & $<.0001$ & & $<.0001$ & 0.72 \\
\hline \multirow{2}{*}{ ALT } & $\mathrm{r}$ & 0.34 & 0.69 & \multirow{2}{*}{1.00} & 0.26 \\
\hline & $\mathrm{p}$ & 0.001 & $<.0001$ & & 0.01 \\
\hline \multirow{2}{*}{ Albumin } & $\mathrm{r}$ & -0.06 & -0.04 & 0.26 & \multirow{2}{*}{1.00} \\
\hline & $\mathrm{p}$ & 0.60 & 0.72 & 0.01 & \\
\hline & & 5: $\mathrm{Cor}$ & ympt & mica & \\
\hline
\end{tabular}

$\mathrm{p}<0.05$ Considered as Statistically Significant; $\mathrm{r}-$ Pearson's Correlation Coefficient.

\section{DISCUSSION}

Hepatitis B virus chronic infection is a major public health problem worldwide because of its complications, such as cirrhosis and HCC. Despite increasing number of papers assessing the prevalence of HBV infection in India and its regional distribution, there is a lack of information about distribution of clinical profile of HBV infection in the country, especially in the eastern part of the country. 5

The age of the patients in the present study varied from 16-76 years. The mean age of the patients was found to be 34.54 years with a standard deviation of 13.53 years. The maximum no. of patients (39\%) was in the age group 21-30 years followed by $27 \%$ in $31-40$ years' age group. Previous study by shah 6 reports a male: female ratio of 2.1:1. The reason for increased prevalence in boys remains unexplained in their patients. However, in the present study, females were predominant and the ratio of female and male with a female: male of 1.17:1.00. We again could not elucidate any plausible mechanisms for the increased prevalence in the female subgroups.
A study by Sathpathy et al. from Delhi points out a strong correlation between elevated SGOT and severity of histological injury. ${ }^{6}$ In a recent study by Shah et al. study they found that AST was elevated in all symptomatic and $64 \%$ asymptomatic patients $(p=0.03)$ suggestive that even if child is asymptomatic, ongoing liver damage is occurring and these patients should be monitored closely. ${ }^{7}$ In the present study, only ALT and serum bilirubin were found to be significantly higher in the symptomatic cohort as compared to the asymptomatic cohort. (Table 3) We could not detect any significant difference between the AST and serum albumin levels. (Table 3) The baseline age was found to be similar in both the symptomatic and asymptomatic cohorts. (Table 3). Furthermore, age was not found to be correlated with any of the biochemical parameters in both of the cohorts.

In our entire study population, we found a strong significant positive correlation found between AST and Bilirubin ( $\mathrm{r}=0.346)$, $\mathrm{p}$ value $=0.0004$, ALT and Bilirubin were also found to be positively correlated ( $r=0.298)$, $p$ value $=0.003$. Similarly, ALT and AST are positively correlated $(r=0.710)$, $p$ value $=<0.0001$ and ALT and Albumin are positively correlated $(\mathrm{r}=0.216)$, $\mathrm{p}$ value $=0.031$ (Moderate significant correlation) in the overall study population. (Table 4) ALT and AST were found to be significantly positively correlated in all of the symptomatic as well as asymptomatic patients in our study sample. (Table $4 \& 5$ ) However, further perusal of the data revealed difference in the correlation coefficients between the symptomatic and asymptomatic cohort. (Table 4 \& 5)

Hepatitis B vaccines provide long-term protection against HBV infection. The primary goal of hepatitis B prevention programs is reduction of chronic $\mathrm{HBV}$ infection and HBV related chronic liver disease. A secondary goal is prevention of acute hepatitis B. Routine hepatitis B immunization programs have resulted in significant reductions in the prevalence of HBV infection among children. In our patients, prior Hepatitis B vaccination may have prevented them from getting Hepatitis B infection. India introduced universal immunization against hepatitis B in 10 states in the year 2002, and in 2011, scaled up this operation countrywide. Recently a pentavalent vaccine, which also protects against HBV has been introduced in some states. ${ }^{8}$

\section{CONCLUSION}

The current study demonstrates the clinical and biochemical features that a hepatitis B infected patient may present with. Most of the patients with hepatitis B are asymptomatic (84\%) on presentation. To our knowledge, this is the first paper reported from Eastern India in recent times which has shed a light on the differences in the pattern of the biochemical parameters among the symptomatic and asymptomatic hepatitis B infected patients.

\section{REFERENCES}

1. Lee WM. Hepatitis B virus infection: a review. N Engl J Med 1997;337:1733-45.

2. Sharma SK, Saini N, Chwla Y. Hepatitis B virus: inactive carriers. Virol J 2005;2:82.

3. Proceedings of the 2 nd national theme symposium on hepatitis B infection in India. Therapeutic options and prevention strategies. New Delhi, september 2 and 3, 2000. Abstracts. Indian J Gastroenterol 2000;19(Suppl 3):C1-82. 
4. Batham A, Gupta MA, Rastogi P, et al. Calculating prevalence of hepatitis $B$ in India: using population weights to look for publication bias in conventional meta-analysis. Indian J Pediatr 2009;76(12):1247-57.

5. Galizzi JF, Teixeira R, Fonseca JC, et al. Clinical profile of hepatitis $B$ virus chronic infection in patients of Brazilian liver reference units. Hepatol Int 2010;4(2):511-5.

6. Satapathy SK, Garg S, Chauhan R, et al. Profile of chronic hepatitis B virus in children in India: experience with 116 children. J Gastroenterol Hepatol 2006;21(7):1170-6.
7. Shah I, Maniar N. Clinical profile of hepatitis B in children in western India. Indian Journal of Medical Specialities 2015;6(1):13-6.

8. Lahariya C, Subramanya BP, Sosler S. An assessment of hepatitis B vaccine introduction in India: lessons for roll out and scale up of new vaccines in immunization programs. Indian J Public Health 2013;57(1):8-14. 